\title{
Effect of water temperature and salinity in oviposition, hatching success and infestation of Aphanoblastella mastigatus (Monogenea, Dactylogyridae) on Rhamdia quelen
}

\author{
N. C. Marchiori ${ }^{*}$, E. L. T. Gonçalves ${ }^{b}$, K. R. Tancredo ${ }^{b}$, J. Pereira-Junior , $^{\text {, }}$ \\ J. R. E. Garcia and M. L. Martins $^{b}$ \\ ${ }^{a}$ Empresa de Pesquisa Agropecuária e Extensão Rural de Santa Catarina - EPAGRI, Campo Experimental de Piscicultura \\ de Camboriú, Rua Joaquim Garcia, s/n, Centro, CEP 88340-000, Camboriú, SC, Brazil \\ bLaboratório de Sanidade de Organismos Aquáticos - AQUOS, Departamento de Aquicultura, Universidade Federal de \\ Santa Catarina - UFSC, Rodovia Admar Gonzaga, 1346, CEP 88040-900, Florianópolis, SC, Brazil \\ 'Laboratório de Biologia de Parasitos de Organismos Aquáticos - LABIPOA, Programa de Pós-graduação em Aquicultura, \\ Universidade Federal do Rio Grande - FURG, Av. Itália, Km 8, Campus Carreiros, \\ CEP 96650-900, Rio Grande, RS, Brazil \\ dUniversidade do Sul de Santa Catarina - Unisul, Av. José Acácio Moreira, 787, Bairro Dehon, CP 370, \\ CEP 88704-900, Tubarão, SC, Brazil \\ *e-mail: namarchiori@gmail.com
}

Received: July 28, 2014 - Accepted: September 23, 2014 - Distributed: November 30, 2015

(With 5 figures)

\begin{abstract}
Several environmental parameters may influence biological processes of several aquatic invertebrates, such as the Monogenea. Current analysis investigates oviposition, hatching success and infestation of Aphanoblastella mastigatus, a parasite of the silver catfish Rhamdia quelen at different temperatures $\left(\sim 24\right.$ and $\left.28^{\circ} \mathrm{C}\right)$ and salinity (by adding sodium chloride to water, at concentrations 0,5 and $9 \mathrm{~g} / \mathrm{L}$ ) in laboratory. There was no significant difference in oviposition rate and in A. mastigatus infestation success at 24 and $28^{\circ} \mathrm{C}$. On the other hand, the concentration $9 \mathrm{~g} / \mathrm{L}$ of sodium chloride in the water impaired the parasite's survival and the viability of the eggs. Results show that its usage is efficient as a possible prophylactic treatment. Eclosion rate of A. mastigatus's eggs was significantly higher at $28^{\circ} \mathrm{C}$, although it was significantly less from $5 \mathrm{~g} / \mathrm{L}$. Two oviposition peaks $(06 \mathrm{~h} 15$ and $18 \mathrm{~h} 15)$ occurred during a 24-hour period, or rather, during the highest variations in luminosity. Further studies are recommended with greater temperature intervals and more intense experimental infestations to verify the effects of temperature in the life span and infestation success of $A$. mastigatus.
\end{abstract}

Keywords: silver catfish, parasitology, water quality, experimental infestation, prophylaxis.

\section{Efeito da temperatura da água e salinidade na oviposição, sucesso de eclosão e infestação de Aphanoblastella mastigatus (Monogenea, Dactylogyridae) em Rhamdia quelen}

\begin{abstract}
Resumo
Diversos parâmetros ambientais podem afetar os processos biológicos de diversos organismos invertebrados aquáticos, como os Monogenea. Neste estudo, nós investigamos a oviposição, sucesso de eclosão e infestação de Aphanoblastella mastigatus, parasito de jundiá Rhamdia quelen, em diferentes condições de temperatura $\left(\sim 24\right.$ e $\left.28{ }^{\circ} \mathrm{C}\right)$ e salinidade (por meio da adição de cloreto de sódio na água nas concentrações de 0,5 e $9 \mathrm{~g} / \mathrm{L}$ ) em laboratório. Não houve diferença significativa na taxa de oviposição nem no sucesso de infestação de $A$. mastigatus à 24 e $28^{\circ} \mathrm{C}$; por outro lado, a concentração de $9 \mathrm{~g} / \mathrm{L}$ de cloreto de sódio na água inviabilizou não só a sobrevivência do parasito mas também a viabilidade dos ovos. Esse resultado indica que seu uso é eficiente como potencial tratamento profilático. A taxa de eclosão dos ovos de A. mastigatus foi significativamente maior a $28^{\circ} \mathrm{C}$. A partir de $5 \mathrm{~g} / \mathrm{L}$, a mesma foi significativamente menor. Durante um período de 24 horas, dois picos na oviposição ocorreram nos momentos de maior variação da luminosidade (06h15 e 18h15). Futuros estudos são recomendados utilizando intervalos de temperatura e intensidades de infestação experimental maiores para verificar a influência da temperatura na longevidade e sucesso de infestação de A. mastigatus.
\end{abstract}

Palavras-chave: jundiá, parasitologia, qualidade da água, infestação experimental, profilaxia. 


\section{Introduction}

Monogenean parasites are economically important pathogen agents in aquaculture (Turgut, 2012). In fact, they are extensively studied in host fish due to their species richness and ubiquity. Whittington (1998) reported that the number of Monogenean species is as large as the number of fish species, with a tentative estimate of more than 25,000 living species, which belong to the above taxon.

The commercially important fish species Rhamdia quelen (Quoy and Gaimard, 1824) (Heptapteridae) cultured in south Brazil, is greatly liable to be infested by Aphanoblastella mastigatus (Suriano, 1986) (Dactylogyridae). It has been recently demonstrated that the oncomiracidium larva of A. mastigatus hatches in 72 hours after oviposition and its life-span as swimming larva has approximately three hours (Marchiori et al., 2013b).

According to Jackson and Tinsley (1998), it is expected that some physiological rates of Monogenean parasites, such as egg production, may be affected by environmental changes. Several studies have shown that temperature variations have a significant influence on the dynamics of the parasite populations (Buchmann, 1988; Jackson and Tinsley, 1998; Ernst et al., 2005; Turgut, 2012). Further, changes in salinity rates may affect the parasites' biological processes and such alterations caused by adding sodium chloride in water may possibly control Monogenea-caused parasitosis (Carneiro et al., 2006; Buchmann et al., 1987; Kubitza, 2007; Souza-Bastos and Freire, 2009).

In this study, oviposition, hatching success and infestation by $A$. mastigatus are investigated at laboratory-controlled different environmental conditions.

\section{Material and Methods}

\subsection{Fish and parasites}

One hundred and twenty-five fish were collected from the Panamá pisciculture ( $27^{\circ} 57^{\prime} 38^{\prime \prime} \mathrm{S}$; $48^{\circ} 45^{\prime} 27^{\prime}$ ' W), municipality of Paulo Lopes, SC, Brazil, between January and April 2012. Fish were transported in plastic bags with oxygen after collection and maintained in a $200 \mathrm{~L}$ tank with filter and aerator at room temperature $\left(24{ }^{\circ} \mathrm{C}\right)$ for 48 hours prior to the start of each experiment.

Fish were fed once a day on extruded commercial ration (Purina) at a proportion of 3\% initially estimated total biomass. Animal feed was suspended at 24 hours prior to the start of experiments on oviposition rates of A. mastigatus at different temperatures and water salinity to avoid feces and make easy the counting of eggs by filtered water.

Several main parameters of water quality, such as dissolved oxygen $(\mathrm{mg} / \mathrm{L}), \mathrm{pH}$, temperature $\left({ }^{\circ} \mathrm{C}\right)$, electrical conductivity $(\mu \mathrm{S} / \mathrm{cm})$, alkalinity $\left(\mathrm{mg} \mathrm{CaCO}_{3} / \mathrm{L}\right)$ and total ammonia $(\mathrm{mg} / \mathrm{L})$, were read daily, at the end of the afternoon, by a microprocessor digital oxygen meter AT 150 , pH meter AT 350, mercury thermometer, microprocessor conductivity meter W12D Bel and calorimeter method
Alfakit, respectively. Fish's biometric data are given as follow: arithmetical means \pm standard deviation and minimum and maximum rates between brackets. Animals submitted to parasitological analysis were anaesthetized with benzocaine $(50 \mathrm{mg} / \mathrm{L})$ and euthanized by deepening the anaesthetized condition. All procedures were undertaken according to the ethical principles of the Ethics Committee of the Universidade Federal de Santa Catarina, Florianópolis, SC, Brazil (UFSC/23080.029980/2009-21).

\subsection{Collection and egg incubation}

Although detailed explication of methods used for the collection of egg may be found in Marchiori et al. (2013a), a summary is given below. Parasitized silver catfish were placed in a central chamber (a $20 \mathrm{~L}$ tank with a cone bottom protected by $41-\mu \mathrm{m}$-mesh plankton net to guarantee the retention of eggs released by the parasite). After 24 hours, the fish were removed from the central chamber, which was suspended so that it could be emptied from water and the eggs kept within the net meshes. The latter were washed and their contents plus eggs were transferred to petri plates where they were incubated until spontaneous eclosion. Oviposition rate was calculated as the number of eggs released by the parasite in 24 hours, following Buchmann (1988).

\subsection{Experimental structure}

Prior to the experiment, thirty fish were collected to warrant the presence of $A$. mastigatus. Fish were then distributed in experimental units, following Marchiori et al. (2013a), and each was used for the experiments described below.

2.3.1. Evaluation of the effect of water temperature on oviposition rate of $A$. mastigatus

Twenty-four fish, $17.82 \pm 2.79(12.5-24.7) \mathrm{cm}$ long and weighing 46.01 \pm 16.10 (15.0-73.8) g, were distributed in 12 experimental units, each with 2 fish per central chamber, for 24 hours. They received the following treatments: (1) fish maintained at $\sim 24{ }^{\circ} \mathrm{C}$ and (2) fish maintained at $\sim 28{ }^{\circ} \mathrm{C}$, with six replications for each group. Different water temperatures were adjusted and controlled by heaters submerged within an integrated thermostat.

\subsubsection{Evaluation of the effect of water salinity on} oviposition rate of $A$. mastigatus

Thirty-six fish, $9.74 \pm 0.75(8.7-12.5) \mathrm{cm}$ long, weighing $6.85 \pm 1.84$ (4.4-14.6) g, were distributed into 18 experimental units, with 2 fish per central chamber, for 24 hours, with the following treatments: (1) fish maintained at $0 \mathrm{~g} / \mathrm{L}$ (de-chloride tap water); (2) fish maintained at $5 \mathrm{~g} / \mathrm{L}$ and (3) fish maintained at $9 \mathrm{~g} / \mathrm{L}$, with six replications for each group. Different water salinities were obtained by adding sodium chloride (iodine-less salt) in water. Water salinity was measured by conductivity meter. Approximate rates $100 ; 8,000$ and $15,000 \mu \mathrm{S} / \mathrm{cm}$ were reported. 
2.3.3. Evaluation of influence of the interaction of different temperatures and water salinities in the experimental infestation of $A$. mastigatus

Sixty-four fish, $13.07 \pm 8.91$ (7.80-14.4) cm long, weighing $11.21 \pm 3.11(6.3-18.2) \mathrm{g}$ were first placed on a formaldehyde therapeutic bath (37\%) diluted in water at a concentration of $0.2 \mathrm{~mL} / \mathrm{L}$, for one hour. After 24 hours, five fish were euthanized to verify the efficiency of formaldehyde on A. mastigatus control. When treatment efficiency was confirmed, the fish were distributed in 18 experimental units with three fish per central chamber and exposed to recently hatched larvae (obtained by technique explained above) at an infestation intensity of 10 larvae per fish. The following treatments (near rates), with three replications each, were evaluated: (1) $24^{\circ} \mathrm{C}-0 \mathrm{~g} / \mathrm{L}$; (2) $28^{\circ} \mathrm{C}-0 \mathrm{~g} / \mathrm{L}$; (3) $24{ }^{\circ} \mathrm{C}-5 \mathrm{~g} / \mathrm{L}$; (4) $28{ }^{\circ} \mathrm{C}-5 \mathrm{~g} / \mathrm{L}$; (5) $24{ }^{\circ} \mathrm{C}-9 \mathrm{~g} / \mathrm{L}$; (6) $28^{\circ} \mathrm{C}-9 \mathrm{~g} / \mathrm{L}$. After 10 days, all the fish were killed to establish the parasitological indexes of $A$. mastigatus, or rather, mean infestation intensity and prevalence, following Bush et al. (1997).

\subsection{Egg embryogeny and hatching success}

Aphanoblastella mastigatus egg agglomerates were transferred to twenty-four 55-mm-diameter petri plates (30 eggs per plate), and left to develop into embryos during the same photoperiod regime as the fish $(12 \mathrm{~h}$ light $/ 12 \mathrm{~h}$ dark). Treatments in triplicate were (1) $24^{\circ} \mathrm{C}$ - tank water (where the fish were kept); (2) $28^{\circ} \mathrm{C}$ - tank water (3) $24^{\circ} \mathrm{C}$-distilled water; (4) $28^{\circ} \mathrm{C}$-distilled water; (5) $24{ }^{\circ} \mathrm{C}-9 \mathrm{~g} / \mathrm{L}$; (6) $28{ }^{\circ} \mathrm{C}-9 \mathrm{~g} / \mathrm{L}$; (7) $24{ }^{\circ} \mathrm{C}-25 \mathrm{~g} / \mathrm{L}$; (8) $28{ }^{\circ} \mathrm{C}-25 \mathrm{~g} / \mathrm{L}$. Partial water exchanges $(50 \%)$ were performed daily in the petri plates. Eggs were evaluated according to their viability until 96 hours after oviposition. Viability estimates were based on the observation of eggs with developed oncomiracidium, with composed eyespots. The different temperatures of the water were controlled by a heating plate with microprocessor temperature control. Different water salinities were obtained by adding sodium chloride to water.

\subsection{Rhythm of oviposition of A. mastigatus}

One fish, $15.7 \mathrm{~cm}$ long and weighing $31 \mathrm{~g}$, was kept in a $20 \mathrm{~L}$ tank with aerator at $24{ }^{\circ} \mathrm{C}$ for 24 hours, with a $12 \mathrm{~h}$ light/12 h dark controlled photoperiod (switched on at $06 \mathrm{~h} 15$ and switched off at 18h15). Water was filtered every three hours with $41-\mu \mathrm{m}$-mesh plankton net and contents transferred to a petri plate for later analysis under a stereomicroscope. The number of eggs released per A. mastigatus adult was established for the same time interval. Some of the main parameters in water quality were measured at the start and end of the experimental period.

\subsection{Statistical analysis}

Data underwent Kolmogorov-Smirnov and Bartlett's tests to verify normality and homocedasticity, respectively. With such presuppositions, data were submitted to unifactorial and factorial analysis of variance (ANOVA) or Student's t test, according to experimental design. Tukey's test was employed to compare means in ANOVA and data transformation was used accordingly. Factorial ANOVA was used if experimental units (tank and central camera) actually caused significant variation as a way to warrant the reliability of results of the investigated experimental designs.

\section{Results}

Results by factorial ANOVA showed that experimental units did not represent significant variation in fish weight and length, number of parasites and number of eggs in each experiment analyzed. There was no significant difference in water quality rates between experimental units in the different treatments investigated (Table 1). Rates were

Table 1. Water quality parameters (mean \pm standard deviation) for each treatment.

\begin{tabular}{|c|c|c|c|c|c|c|}
\hline & $\begin{array}{c}\text { Water } \\
\text { temperature } \\
\left({ }^{\circ} \mathrm{C}\right)\end{array}$ & $\begin{array}{c}\text { Electrical } \\
\text { conductivity } \\
(\mu \mathrm{S} / \mathrm{cm})\end{array}$ & $\begin{array}{c}\text { Dissolved } \\
\text { oxygen } \\
\text { (mg/L) }\end{array}$ & pH & $\begin{array}{c}\text { Alkalinity } \\
\left(\mathrm{mg} \mathrm{CaCO}_{3} / \mathrm{l}\right)\end{array}$ & $\begin{array}{c}\text { Total } \\
\text { ammonia } \\
(\mathrm{mg} / \mathrm{L})\end{array}$ \\
\hline \multicolumn{7}{|c|}{ 1. Temperature } \\
\hline 24 & $24.10 \pm 0.63$ & $90.33 \pm 19.76$ & $9.0 \pm 0$ & $7.95 \pm 0.56$ & $19.16 \pm 4.91$ & $0.30 \pm 0.21$ \\
\hline 28 & $28.30 \pm 0.80$ & $95.50 \pm 21.04$ & $9.2 \pm 0.40$ & $7.90 \pm 0.54$ & $25 \pm 4.47$ & $0.33 \pm 0.31$ \\
\hline \multicolumn{7}{|c|}{ 2. Salinity (g/L) } \\
\hline 0 & $23.80 \pm 0.34$ & $104 \pm 16.10$ & $9.6 \pm 0.26$ & $8.10 \pm 0.47$ & $40 \pm 0$ & $0.25 \pm 0$ \\
\hline 5 & $24.23 \pm 0.05$ & $8,566 \pm 452$ & $9.0 \pm 0.70$ & $7.60 \pm 0.36$ & $40 \pm 0$ & $0.41 \pm 0.14$ \\
\hline 9 & $23.39 \pm 0.90$ & $14,667 \pm 289$ & $9.0 \pm 1$ & $7.8 \pm 0$ & $40 \pm 0$ & $0.25 \pm 0$ \\
\hline \multicolumn{7}{|c|}{ 3. Temperature $\times$ salinity $(\mathrm{g} / \mathrm{L})$} \\
\hline $24-0$ & $23.5 \pm 0.86$ & $120 \pm 30$ & $9.4 \pm 0.50$ & $8.0 \pm 0.20$ & $32 \pm 2$ & $0.25 \pm 0.30$ \\
\hline $28-0$ & $28.6 \pm 10$ & $83.33 \pm 20.81$ & $9.0 \pm 0.70$ & $7.86 \pm 0.20$ & $40 \pm 0$ & $0.40 \pm 0$ \\
\hline $24-5$ & $23.66 \pm 0.57$ & $8,500 \pm 200$ & $9.2 \pm 1$ & $7.5 \pm 0.17$ & $40 \pm 0$ & $0.23 \pm 0.23$ \\
\hline $28-5$ & $29.33 \pm 1.15$ & $9,100 \pm 264$ & $9.4 \pm 0$ & $7.3 \pm 0.10$ & $27 \pm 3.68$ & $0.40 \pm 0$ \\
\hline $24-9$ & $25.13 \pm 1.02$ & $12,920 \pm 950$ & $9.2 \pm 0.40$ & $7.0 \pm 0.30$ & $38.8 \pm 1.40$ & $0.40 \pm 0$ \\
\hline $28-9$ & $28 \pm 0$ & $15,336 \pm 342$ & $9.4 \pm 0$ & $7.3 \pm 0.05$ & $40 \pm 0$ & $0.40 \pm 0$ \\
\hline
\end{tabular}


within adequate levels for the development of the silver catfish, following Piedras et al. (2004) and Baldisserotto and Radünz Neto (2004).

\subsection{Influence of water temperature in oviposition}

No significant difference in the oviposition rate of A. mastigatus occurred between $24^{\circ} \mathrm{C}$ and $28^{\circ} \mathrm{C}$, and in the total number of eggs (Figure $1 \mathrm{~b}, \mathrm{c}$ ). There was significant difference $(\mathrm{p}<0.05)$ in the number of adult parasites for the two temperatures under analysis (Figure 1a).

\subsection{Influence of water salinity on oviposition}

Whereas the number of adult parasites and oviposition rate did not differ significantly at concentrations 0 and $5 \mathrm{~g} / \mathrm{L}$ of sodium chloride in water, they were significantly lower
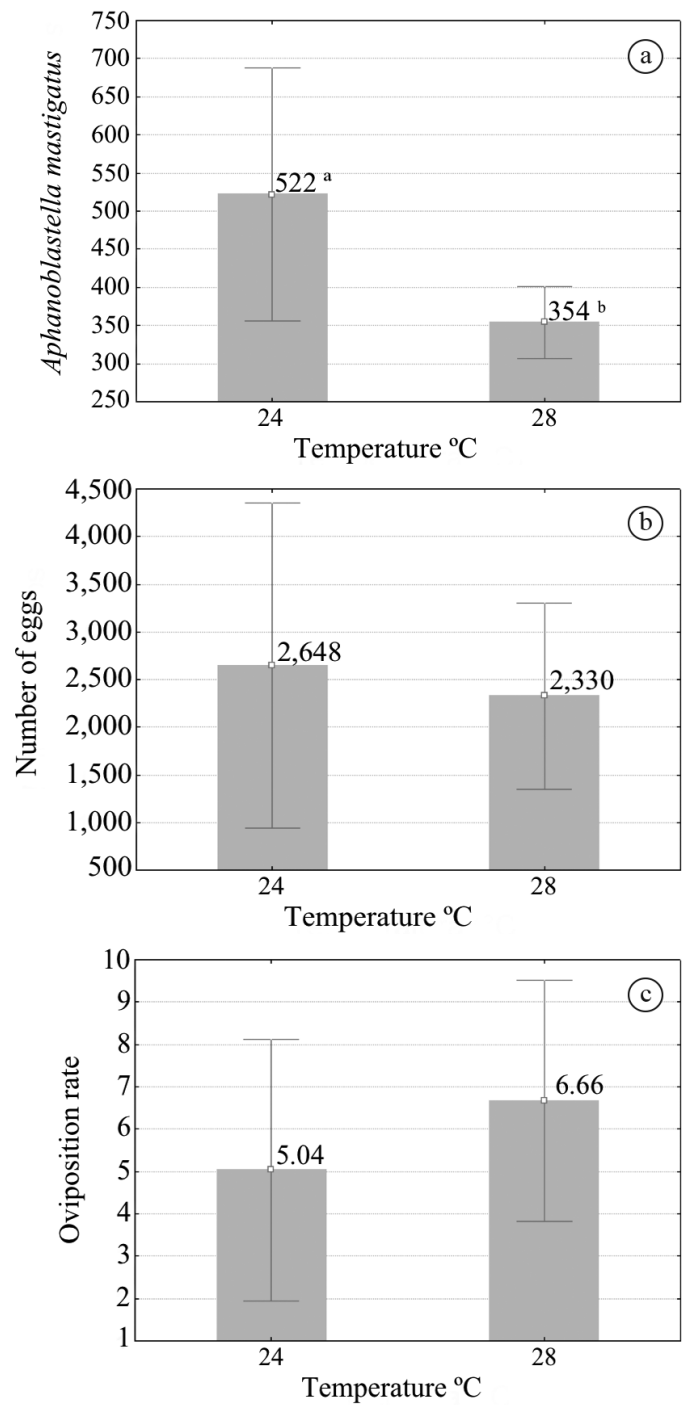

Figure 1. Mean rates with $95 \%$ confidence interval (vertical bars) at different temperatures: (a) number of adult parasites of Aphanoblastella mastigatus; (b) total number of eggs; (c) oviposition rate. Different letters mean significant differences (Student's t test). at $9 \mathrm{~g} / \mathrm{L}$ (Figure $2 \mathrm{a}, \mathrm{c}$ ). The total number of eggs collected was significantly higher at concentration $0 \mathrm{~g} / \mathrm{L}$ and significantly less at $9 \mathrm{~g} / \mathrm{L}$ (Figure $2 \mathrm{~b}$ ). No adult parasites were found in the gills of the silver catfish maintained at a concentration of $9 \mathrm{~g} / \mathrm{L}$.

\subsection{Embryogeny of eggs and hatching success}

Aphanoblastella mastigatus eggs in both temperatures hatched at $0 \mathrm{~g} / \mathrm{L}$ as from 72 hours after oviposition. Eclosion rate, however, was significantly higher at $28^{\circ} \mathrm{C}$ (88\%) when compared to $24^{\circ} \mathrm{C}(56 \%)$. Eggs hatched in
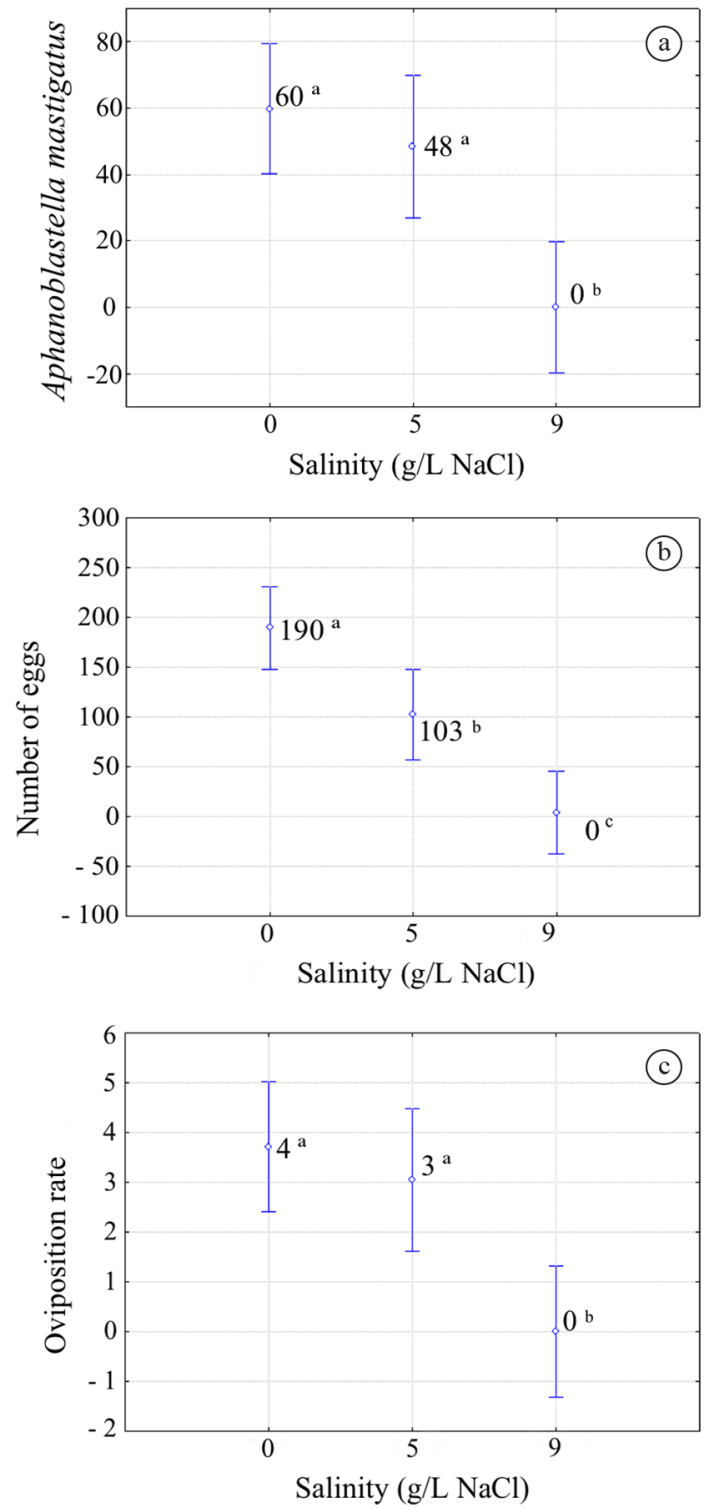

Figure 2. Mean rates with $95 \%$ confidence interval (vertical bar) in different salinities: (a) number of adult parasites of Aphanoblastella mastigatus; (b) total number of eggs; (c) oviposition rate. Different letters mean significant difference (unifactorial ANOVA). 
distilled water as from 96 hours for the two temperatures under analysis. There was no significant difference in the eclosion rate between temperatures $\left(55 \%\right.$ at $28{ }^{\circ} \mathrm{C} ; 44 \%$ at $\left.24^{\circ} \mathrm{C}\right)$. Eclosion rate at 9 and $25 \mathrm{~g} / \mathrm{L}$ was significantly lower than that in the other treatments for the two temperatures (Figure 3).

\subsection{Influence of the interaction between different temperatures and water salinity in infestation of A. mastigatus}

Factorial ANOVA failed to identify any significant interaction between the analyzed variables (Figure 4c). Factors were consequently analyzed one by one. There was no significant difference for temperatures, although salinity had a significant influence $(\mathrm{p}<0.05)$ on the infestation by $A$. mastigatus at the different rates under analysis (Figure $4 \mathrm{a}-\mathrm{c}$ ). Table 2 shows the indexes of mean infestation intensity and prevalence obtained in current experiment. No parasite was found in the fish gills maintained in treatment with the addition of $9 \mathrm{~g} / \mathrm{L}$ of sodium chloride in water. Highest parasite prevalence occurred in treatment (2) $28^{\circ} \mathrm{C}-0 \mathrm{~g} / \mathrm{L}$.

\subsection{Rhythm of oviposition of Aphanoblastella mastigatus}

Rates for water quality parameters were constant, with the exception of electrical conductivity of water and $\mathrm{pH}$ (Table 3). Figure 5 shows the number of $A$. mastigatus eggs collected at 3-hour intervals within a period of 24 hours. Two oviposition peaks occurred at the greatest luminosity changes (18h15 and 06h15).

\section{Discussion}

Temperature and salinity are two relevant environmental parameters that affect the biological processes of several water invertebrates such as Monogenea (Mooney et al.,

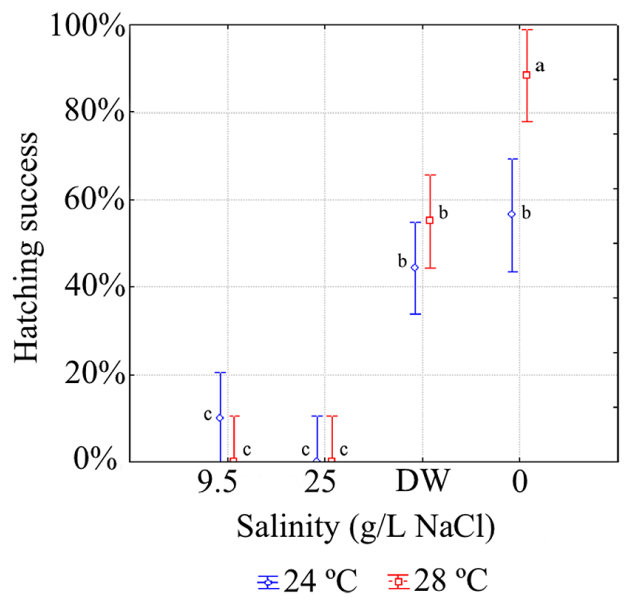

Figure 3. Mean rates of hatching success of Aphanoblastella mastigatus with $95 \%$ confidence interval (vertical bar) at different temperatures and water salinity. $\mathrm{DW}=$ distilled water. Different letters mean significant difference (factorial ANOVA).
2008). Several studies show a positive co-relationship between an increase in water temperature and oviposition rate of Monogenea (Buchmann, 1988; Jackson and Tinsley, 1998; Tubbs et al., 2005; Turgut, 2012). As in current study, Buchmann (1988) and Paperna (1963) failed to detect a significant difference in oviposition rates in Pseudactylogyrus bini Kiknuchi, 1929 (Dactylogyridae) and Dactylogyrus vastator Nybelin, 1924 (Dactylogyridae), respectively, at an interval between 24 and $28^{\circ} \mathrm{C}$. However,
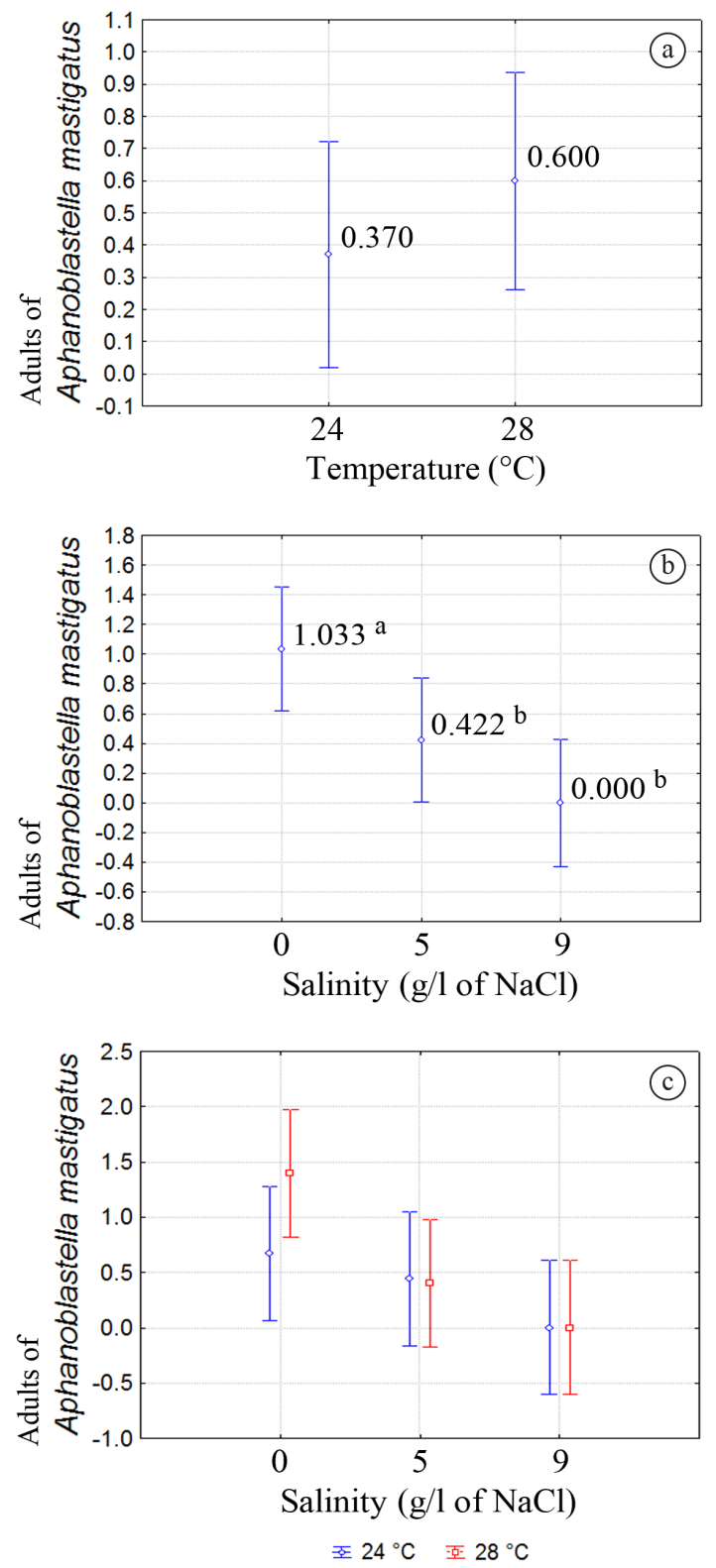

Figure 4. Mean rates with $95 \%$ confidence intervals (vertical bar) in the experimental infestation of Aphanoblastella mastigatus at different (a) temperatures; (b) salinity and (c) interaction between water salinities and temperatures. Different letters show significant difference (factorial ANOVA). 
Table 2. Parasitological indexes (mean \pm standard deviation) of Aphanoblastella mastigatus in Rhamdia quelen.

\begin{tabular}{ccc}
\hline & Parasitological Indexes & \\
\hline Temperature $\left({ }^{\circ} \mathbf{C}\right)-$ Salinity $(\mathbf{g} / \mathbf{L})$ & Mean intensity of infestation & Prevalence $(\mathbf{\%})$ \\
\hline $24-0$ & $2 \pm 1$ & $33 \%$ \\
$28-0$ & $2 \pm 1.15$ & $70 \%$ \\
$24-5$ & $2 \pm 0$ & $22 \%$ \\
$28-5$ & $2 \pm 1.41$ & $20 \%$ \\
$24-9$ & $0 \pm 0$ & 0 \\
$28-9$ & $0 \pm 0$ & 0 \\
\hline
\end{tabular}

Table 3. Rhythm of oviposition of Aphanoblastella mastigatus (Suriano, 1986). Physical and chemical parameters of water measured at the start and end of a 24-h period.

\begin{tabular}{lcc}
\hline & Start & End \\
\hline Water quality parameters & & \\
Temperature $\left({ }^{\circ} \mathrm{C}\right)$ & 23 & 23 \\
Total ammonia $(\mathrm{mg} / \mathrm{L})$ & 0.1 & 0.1 \\
Dissolved oxygen $(\mathrm{mg} / \mathrm{L})$ & 9.2 & 9.2 \\
Electrical conductivity $(\mu \mathrm{S} / \mathrm{cm})$ & 101 & 80 \\
$\mathrm{pH}$ & 7.8 & 8.4 \\
\hline
\end{tabular}

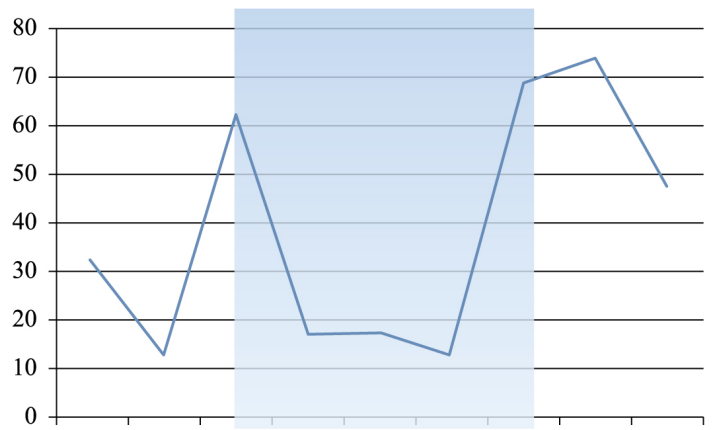

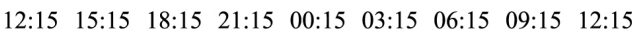
Time (hours) - Series 1

Figure 5. Rhythm of oviposition. Number of Aphanoblastella mastigatus eggs collected at 3-hour intervals within a 24-h period.

it may not be concluded that temperature does not affect the oviposition process of $A$. mastigatus. Results suggest that the analyzed interval was not enough to evidence significant variations. The number of adult parasites in current study varied significantly between the temperatures analyzed. The authors believe that this fact may have occurred due to differences in initial parasite intensity in the hosts used (control not possible). Kubitza (2007) recommends that common salt $(\mathrm{NaCl})$ in concentrations between 10 and $50 \mathrm{~g} / \mathrm{L}$ can be used to control protozoan parasites and Monogenea (exposure time between 12 hours and 20 seconds), whereas Souza-Bastos and Freire (2009) suggest $15 \mathrm{~g} / \mathrm{L}$ concentration of exposure time of one hour for the treatment of Ichthyophthirius multifiliis
Fouquet, 1876 in silver catfish (R. quelen). Marchioro and Baldisserotto (1999) concluded that $R$. quelen accepted $\mathrm{NaCl}$ concentrations in water up to $9 \mathrm{~g} / \mathrm{L}$ for 96 hours without any death, albeit with changes in feed behavior. According to results in current analysis, treatment in $5 \mathrm{~g} / \mathrm{L}$ concentration for 24 hours was not sufficient for the parasites to be completely eliminated. However, live adult parasites were not extant in fish maintained at $9 \mathrm{~g} / \mathrm{L}$. The above result, coupled to the survival of all the silver catfish, reiterates its use as a potential prophylactic treatment for the fish.

Factors that favored eclosion of $A$. mastigatus eggs were not analyzed in current study. However, results show that the species has the capacity of spontaneous eclosion even in the absence of the host's stimuli, very similar to what Whittington and Kearn (2011) concluded in the case of Entobdella soleae (van Beneden and Hesse, 1863) (Capsalidae). Although a 24-h delay interval was reported in the eclosion time of $A$. mastigatus eggs kept in distilled water, the same were nevertheless hatched. Temperatures of analyzed water did not affect the eclosion time of A. mastigatus, but a significant difference $(\mathrm{p}<0.05)$ was detected in the eclosion rate. The above suggests that high temperatures may favor the development of viable eggs and thus contribute towards an increase in the infestation success of $A$. mastigatus. Results for egg eclosion rate at salinities over $9 \mathrm{~g} / \mathrm{L}$ demonstrate that the concentration is efficient in the species's parasite control.

Available literature on experimental infestation studies with Monogenea indicates different infestation intensities. Whereas Buchmann (1988) used 5 to 14 larvae of P. bini per fish (Anguilla anguilla), Gannicott and Tinsley (1998) employed 100 larvae of Discocotyle sagittata (Leuckart, 1842) (Discocotylidae) per fish (Oncorhynchus mykiss (Walbaum, 1792)). Results obtained in current analysis showed that infestation intensity of $10 \mathrm{~A}$. mastigatus larvae per host was very low and may explain the low parasitological indexes. Further, the life span of $A$. mastigatus larvae at $24^{\circ} \mathrm{C}$ is low (Marchiori et al., 2013b). This fact may have affected the low indexes observed. Although the highest prevalence of $A$. mastigatus has been reported in the treatment $(2) 28^{\circ} \mathrm{C}-0 \mathrm{~g} / \mathrm{L}$, the statistical analysis did not differ significantly between the temperatures tested during the experimental infestation. Further studies with higher temperature intervals and infestation intensities (between 50 and 100 larvae per host) are recommended 
to verify the influence of temperature in the life span and infestation success of $A$. mastigatus.

Time and manner by which the eggs are released by parasites may affect significantly hatching success and host infestation (Whittington and Kearn, 2011). Mooney et al. (2008) studied the daily oviposition rhythm of Monogenea sea species of Seriola quinqueradiata Temminck \& Schlegel, 1845 and concluded that, whereas Heteraxine heterocerca (Goto, 1894) (Heteraxinidae) had a well-defined rhythm for egg release ( $45 \%$ of the eggs were released during the first three hours of the dark period), Benedenia seriolae (Yamaguti, 1934) (Capsalidae) released eggs continually during the day. Oviposition rhythm for $H$. heterocerca is similar to that of Zeuxapta seriolae (Meserve, 1938) (Axinidae), a parasite of Seriola lalandi Valenciennes, 1833 , in which $75 \%$ of the daily production of eggs is released during the first three hours of the dark period (Mooney et al., 2006). It is highly relevant to underscore that these species accumulate great amounts of eggs in their uterus, contrastingly to A. mastigatus which does not accumulate eggs in the uterus but produce and release them one by one. A large number of eggs retained in the plankton mesh during the two periods with the highest luminosity changes (06h15 and $18 \mathrm{~h} 15$ for the photoperiod described) was reported. The above suggests that light changes somewhat affect oviposition of the species analyzed. However, result occurred from data collected in a short time period (24 hours, without any replication) and the relationship cannot be confirmed without a longer observation.

\section{Acknowledgements}

The authors would like to thank The Brazilian Council for Scientific and Technological Development (CNPq) for scholarship to M.L. Martins (CNPq 302493/2010-7). Thanks are also due to the Coordination for the Improvement of Higher Education Personnel (CAPES) for funding research by N.C. Marchiori and J. Pereira Jr. (Proc. 1272/11).

\section{References}

BALDISSEROTTO, B. and RADÜNZ NETO, J., 2004. Criação de jundiá. Santa Maria: UFSM. 232 p.

BUCHMANN, K., 1988. Temperature-dependent reproduction and survival of Pseudodactylogyrus bini (Monogenea) on the european eel (Anguilla anguilla). Parasitology Research, vol. 75, no. 2, pp. 162-164. http://dx.doi.org/10.1007/BF00932717.

BUCHMANN, K., MELlERGAARD, S. and KOIE, M., 1987. Pseudodactylogyrus infections in eel: a review. Diseases of Aquatic Organisms, vol. 3, pp. 51-57. http://dx.doi.org/10.3354/dao003051.

BUSH, A.O., LAFFERTY, K.D., LOTZ, J.M. and SHOSTAK, A.W., 1997. Parasitology meets ecology on its own terms: Margolis et al. revisited. The Journal of Parasitology, vol. 83, no. 4, pp. 575-583. http://dx.doi.org/10.2307/3284227. PMid:9267395.

CARNEIRO, P.C.F., CIRIO, S.M. and SCHORER, M., 2006. Estudo anatomopatológico de alevinos de jundiás infectados experimentalmente por Ichthyophthirius multifiliis e submetidos a tratamentos convencionais. Archives of Veterinary Science, vol. 11, no. 1, pp. 33-38. http://dx.doi.org/10.5380/avs.v11i1.5620.

ERNST, I., WHITTINGTON, I.D., CORNEILLIE, S. and TALBOT, C., 2005. Effects of temperature, salinity, desiccation and chemical treatments on egg embryonation and hatching success of Benedenia seriolae (Monogenea, Capsalidae), a parasite of farmed Seriola spp. Journal of Fish Diseases, vol. 28, no. 3, pp. 157-164. http:// dx.doi.org/10.1111/j.1365-2761.2004.00605.x. PMid:15752276.

GANNICOTT, A.M. and TINSLEY, R.C., 1998. Environmental effects on transmission of Discocotyle sagittata (Monogenea): egg production and development. Parasitology, vol. 117, no. Pt 5, pp. 499-504. http://dx.doi.org/10.1017/S0031182098003205. PMid:9836315.

JACKSON, J.A. and TINSLEY, R.C., 1998. Effects of temperature on oviposition rate in Protopolystoma xenopodis (Monogenea: Polystomatidae). International Journal for Parasitology, vol. 28, no. 2, pp. 309-315. http://dx.doi.org/10.1016/S0020-7519(97)001513. PMid:9512994.

KUBITZA, F., 2007. A versatilidade do sal na piscicultura. Panorama da Aquicultura, vol. 17, pp. 14-27.

MARCHIORI, N., TANCREDO, K., ROUMBEDAKIS, K., GONÇALVES, E.L.T., PEREIRA JUNIOR, J. and MARTINS, M.L., 2013a. New technique for collecting eggs from monogenean parasites. Experimental Parasitology, vol. 134, no. 2, pp. 138-140. http://dx.doi.org/10.1016/j.exppara.2013.02.011. PMid:23500621.

MARCHIORI, N., TANCREDO, K. and PEREIRA JUNIOR, J., CASTRO, L.A.S. and MARTINS, M.L., 2013b. Early development of Aphanoblastella mastigatus (Suriano, 1986) with special reference to egg and oncomiracidium. In: Proceedings of the 7th International Symposium on Monogenea, 2013, Rio de Janeiro. Curitiba: UFPR.

MARCHIORO, M.I. and BALDISSEROTTO, B., 1999. Sobrevivência de alevinos de jundiá (Rhamdia quelen Quoy \& Gaimard, 1824) à variação de salinidade de água. Ciência Rural, vol. 29, no. 2, pp. 315-318. http://dx.doi.org/10.1590/S0103-84781999000200021.

MOONEY, A.J., ERNST, I. and WHITTINGTON, I., 2006. An egg-laying rhythm in Zeuxapta seriolae (Monogenea: Heteraxinidae), a gill parasite of yellowtail kingfish (Seriola lalandi). Aquaculture, vol. 253, no. 1-4, pp. 10-16. http://dx.doi. org/10.1016/j.aquaculture.2004.11.029.

MOONEY, A.J., ERNST, I. and WHITTINGTON, I., 2008. Egglaying patterns and in vivo egg production in the monogenean parasites Heteraxine heterocerca and Benedenia seriolae from japanese yellowtail Seriola quinqueradiata. Parasitology, vol. 135, no. 11, pp. 1295-1302. http://dx.doi.org/10.1017/ S0031182008004691. PMid:18700993.

PAPERNA, I., 1963. Some observations on the biology and ecology of Dactylogyrus vastator in Israel. The Israeli Journal of Aquaculture-Bamidgeh, vol. 15, pp. 8-28.

PIEDRAS, S.R.N., MORAES, P.R.R. and POUEY, J.L.O.F., 2004. Crescimento de juvenis de jundiá (Rhamdia quelen), de acordo com a temperatura da água. Boletim do Instituto de Pesca, vol. 30, pp. 177-182.

SOUZA-BASTOS, L.R. and FREIRE, C.A., 2009. The handling of salt by the neotropical cultured freshwater fish Rhamdia quelen. Aquaculture, vol. 289, no. 1-2, pp. 167-174. http://dx.doi. org/10.1016/j.aquaculture.2009.01.007.

TUBBS, L.A., POORTENAAR, C.W., SEWELL, M.A. and DIGGLES, B.K., 2005. Effects of temperature on fecundity in vitro, 
egg hatching and reproductive development of Benedenia seriolae and Zeuxapta seriolae (Monogenea) parasitic on yellowtail kingfish Seriola lalandi. International Journal for Parasitology, vol. 35, no. 3, pp. 315-327. http://dx.doi.org/10.1016/j.ijpara.2004.11.008. PMid:15722083.

TURGUT, E., 2012. Influence of temperature and parasite intensity on egg production and hatching of the monogenean Dactylogyrus extensus. The Israeli Journal of Aquaculture-Bamidgeh, vol. 64, pp. 729-733.
WHITTINGTON, I.D. and KEARN, G.C., 2011. Hatching strategies in monogenean (Platyhelminth) parasites that facilitate host infection. Integrative and Comparable Biology, vol. 51, no. 1, pp. 91-99. http://dx.doi.org/10.1093/icb/icr003. PMid:21558179.

WHITTINGTON, I.D., 1998. Diversity down under: monogeneans in the antipodes Australia with a prediction of monogenean biodiversity worldwide. International Journal for Parasitology, vol. 28 , no. 10, pp. 1481-1493. http://dx.doi.org/10.1016/S00207519(98)00064-2. PMid:9801912. 